\title{
Tiltak rundt innledning av anestesi til barn
}

Sammendrag skrevet av

Liv Merete Reinar ved Nasjonalt kunnskapssenter for helsetjenesten Illustrasjon: Lene Ask

At foreldre er til stede ved innledning av anestesi reduserer ikke angst hos barna. Men noen andre tiltak er lovende for å redusere angst hos barna: å gi foreldre akupunktur, bruke «klovnedoktor», hypnose, lavt stimuleringsnivå og å gi barna håndholdte videospill. Slik konkluderer Cochrane-samarbeidet etter en systematisk gjennomgang av relevant forskningslitteratur.

Barn kan få beroligende medikamenter før de får anestesi, men disse kan ha uønskede bivirkninger som pusteproblemer eller uønsket atferd etter operasjon.

Hvilke ikke-farmakologiske tiltak virker? Studiene viste at:

- Foreldrenes tilstedeværelse fører trolig ikke til mindre angst hos barn som får anestesi

- Barna samarbeider trolig heller ikke bedre med helsepersonell dersom foreldrene er til stede

- Interaktive dataspill kan muligens hjelpe barna til å samarbeide bedre og reduserer også negativ atferd i oppvåkningsfasen etter operasjon
- Bruk av videospill kan muligens redusere angst hos barna

- «Klovnedoktorer» kan muligens redusere angst hos barn, men ikke hos foreldre

- Hypnose til barn forer muligens til færre engstelige barn enn bruk av medikamenter

- Barna samarbeider muligens bedre dersom de er i et miljø med lavt stimuleringsnivå

\section{KVALITET PÅ \\ DOKUMENTASJONEN}

Vi skiller mellom dokumentasjon av høy, middels, lav eller svært lav kvalitet. Jo høyere kvalitet, jo mer kan vi stole på dokumentasjonen. Åtte studier hadde vurdert effekten av foreldrenes tilstedeværelse. For de andre tiltakene er konklusjonene basert på enkeltstudier av middels kvalitet. For disse tiltakene trengs det flere studier for å kunne styrke dokumentasjonsgrunnlaget.

\section{HVA ER DENNE INFORMA- SJONEN BASERT PÅ?}

Et internasjonalt forskerteam lette etter studier som har undersøkt effekten av ikke-farmakologiske tiltak ved induksjon av anestesi til barn. Tiltakene hadde til hensikt å redusere angst og uro samt oke barnas samarbeidsvilje.

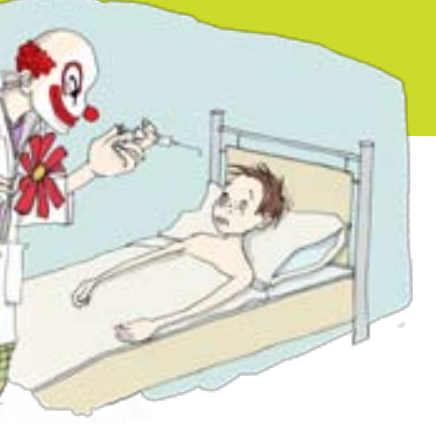

Forskerne fant 17 studier som oppfylte kravene de hadde fastsatt på forhånd. Disse studiene hadde til sammen 1796 deltakere (barn, foreldre eller begge deler). Hovedvekten av studiene var utført i USA, resten var fra Europa og Japan. Forskerne hadde vurdert effekten av:

- foreldres tilstedeværelse versus ikke tilstedeværelse

- foreldres tilstedeværelse versus midazolam (benzodiazepam)

- foreldres tilstedeværelse versus foreldres tilstedeværelse pluss midazolam (benzodiazepam)

- tegneserier, videospill, "klovnedoktor», hypnose, lavt stimuli eller musikkterapi rettet mot barn

- akupunktur eller undervisningsvideo rettet mot foreldre

\section{KILDE}

Yip P, Middleton P, Cyna AM, Carlyle AV. Non-pharmacological interventions for assisting the induction of anaesthesia in children. Cochrane Database of Systematic Reviews 2009, Issue 3. Art. No.: CD006447. DOI: 10.1002/14651858. CD006447.pub2.

Les hele artikkelen i Cochrane Library (gratis tilgang via www. cochrane.no) 